Журнал«Герстективита інновації наукиљ

(Серія«Гедагогіка», Серія«Гцихологія», Серія«Медицинв»

№(6) 2022

УДК 373.5.015.31:613.955

https://doi.org/10.52058/2786-4952 -2022-1(6)-194-202

Кондрацька Галина Дмитрівна доктор педагогічних наук, професор, завідувач кафедри спортивних дисциплін і туризму, Дрогобицький державний педагогічний університет імені Івана Франка, вул Театральна 2, м. Дрогобич, 82100, https://orcid.org/0000-0001-8856-1125

\title{
РОЛЬ ПРОСВІТНИЦЬКОЇ РОБОТИ В ЗАКЛАДАХ ОСВІТИ 3 МЕТОЮ ФОРМУВАННЯ ЗДОРОВОГО СПОСОБУ ЖИТТЯ УЧНІВСЬКОЇ МОЛОДІ
}

Анотація. У статті розглядається питання впливу педагогіки на формування світоглядної політики закладів освіти. Розглянуто роль просвітницької роботи серед учнів та студентів як важливої складової у формуванні знань про здоровий спосіб життя, фактори які визначають індивідуальну освітню траєкторію кожної особистості зокрема. Встановлено, що проблема формування здорового способу життя учнів та студентів потребує впровадження системи просвітницьких заходів. Визначено вплив освіти на етапи формування здорового способу життя учнівської молоді. Складна епідеміологічна ситуація у світі вимагає постійного моніторингу для визначення сучасних тенденцій щодо формування компетентностей здорового способу життя учнівської молоді. Вказано, програми розвитку та формування здорового способу життя учнівської молоді через патріотичне виховання наслення, розвитку духовності та зміцнення маральних засад суспільства, соціальні програми, які можуть ефективно реалізуватися в оздороувчих центрах, освітніх закладах. Виділено п’ять траєкторій просвітницького руху у формуванні здорового способу життя учнівської молоді: культурно-просвітницький, фізкультурно-оздоровчий, реабілітаційнопрофілактичний, загальногігіенічний, рекреаційно-екологічний. Результатом проведеного дослідження $є$ здійснення контекстуально-компаративістичного аналізу педагогічних поглядів до проблеми просвітницької діяльності у формуванні здорового способу життя учнівської молоді визначено, що саме ініціатива: освітніх, соціальних, бізнес-структур, релігійних організацій мають підтримувати, керувати і координувати процес формування здорового способу життя населення України.

Ключові слова: просвітницька діяльність здоровий спосіб життя, учнівська молодь.

Kondratska Halyna Dmytrivna Doctor of Pedagogical Sciences, Professor, Head of the Department of Sports Disciplines and Tourism, Ivan Franko Drohobych State Pedagogical University, 2 Teatralna St., Drohobych, 82100, https://orcid.org/0000-0001-8856-1125 


\title{
THE ROLE OF EDUCATIONAL WORK IN EDUCATIONAL INSTITUTIONS WITH THE PURPOSE OF FORMING A HEALTHY LIFESTYLE FOR STUDENT YOUTH
}

\begin{abstract}
The article considers the issue of the influence of pedagogy on the formation of worldview policy of educational institutions. The role of educational work among pupils and students as an important component in the formation of knowledge about a healthy lifestyle, the factors that determine the individual educational trajectory of each individual in particular. It is established that the problem of forming a healthy lifestyle of pupils and students requires the introduction of a system of educational activities. The influence of education on the stages of formation of a healthy lifestyle of student youth is determined. The complex epidemiological situation in the world requires constant monitoring to identify current trends in the formation of competencies for a healthy lifestyle of young students. The programs of development and formation of a healthy way of life of student's youth through patriotic education of the population, development of spirituality and strengthening of moral bases of society, social programs which can be effectively realized in the health centers, educational institutions are specified. There are five trajectories of the educational movement in the formation of a healthy lifestyle of young students: cultural and educational, physical culture and health, rehabilitation and prevention, general hygiene, recreational and environmental. The result of the study is a contextual-comparative analysis of pedagogical views on the problem of educational activities in the formation of a healthy lifestyle of young students. It is determined that the initiative: educational, social, business structures, religious organizations should support, manage and coordinate Of Ukraine.
\end{abstract}

Keywords: educational activity, healthy lifestyle, student youth.

Постановка проблеми. 3 часу проголошення незалежності України наростає тенденція активного перегляду, переосмислення та об'єктивного висвітлення освітнього процесу в Україні. Інтенсивно розвиваються різні галузі знань в усіх сферах суспільного життя, і серед них - в освітня. Триває бурхливий процес розвитку науки і техніки, проводяться глибокі дослідження історико-педагогічної спрямованості.

Педагогічна освіта сьогодні - це один із найпоширеніших напрямів історико-педагогічних досліджень, тому існують труднощі аналізу та популяризації їхньої творчої спадщини. Вивчення теоретичного і практичного доробку в галузі педагогіки тепер повертається до нас через ідеї, цікаві міркування, дотичні до побудови освітнього процесу, структурних компонентів процесу навчання тощо, які актуальні й для сучасного шкільництва. На сучасному етапі актуальним і доцільним, $є$ висвітлення науково-педагогічної та просвітницької діяльності сучасних науковців, дослідників їх педагогічних світоглядних ідей. 
Журнал«Герспективитаінновації наукиљ

(Серія «Гедагогіка», Серія«ГЕихологія», Серія«Медицина»

№1(6) 2022

Історично склалося так, що впродовж останього XX століття вагомим внеском у розробку теорії формування здорового способу життя стали дослідження канадського та південноамериканського регіонів. Ці проекти, спрямовані на позитивний впливна усі сфери здоровя, що втілюється на засадах партнерства 3 різними муніципальними, суспільними, приватними, релігійними структурами. Науковцями представлено закордонні проекти формування здорового способу життя на досвіді Канади і США. Оскільки вітчизняних проектів суттєво менше за кількістю, тому важливо їх використовути з просвітницькою метою.

Це дає можливість простежити роль і місце просвітницької діяльності у формуванні індивідуальної траєкторії здорового способу життя сучасної молоді.

Аналіз останніх досліджень і публікацій. Науковий пошук, теоретикометодологічний аналіз історичних процесів і явищ дає можливість вивчити етапність впливу просвітницької діяльності на формування здорового способу життя людини.

Для того, щоб сформувати особистість яка б прагнула здорового способу життя, потрібно передати ій історичний досвід українського народу накопичений в аспекті формування здорової, загартованої особистості.

Виховання дітей у первісній дородовій общині мало в основному наслідувальний характер, вирішальний вплив на виховання мала праця. В епоху палеоліту вихованням дітей, в тому числі фізичним, займалася релігія. Поступово впродовж багатьох тисячоліть виховання відокремлювалося від загального процесу діяльності людини. Значним показником інтересу давніх словян до формування здорового покоління можуть служити ініціації юнаків. Цікавим досвідом ділиться Балушок В. [1], дослідник вважає юнацькі ініціації - це школа сили і мужності. Змужніння і соціальний стан молоді в архаїчному i традиційному суспільствах у багатьох народів супроводжували особливі обряди - молодіжні ініціації. Оскільки в архаїчному та традиційному суспільствах дуже високо цінувалась чоловіча сила, спритність і витривалість, на виховання цих якостей у чоловічої молоді і спрямовувалися обряди, що супроводжували іï соціалізацію. Це було властивим і традиційним ініціаціям наших предків - давніх словян. Балушок В. [1] підтверджує, що давньословянські юнацькі ініціації справді були суворою школою, яка виховала здорових, загартованих людей, на яких змогло б покластися суспільство.

Винекнення перших шкіл в Давній Русі дало початок новим формам i методам фізичного виховання дітей, 3 одного боку діти виховувалися під впливом християнських віровчень, 3 другого боку фізична витривалість виховувалась за допомогою народних традицій, виражених в народних забавах, рухових іграх та прислів'ях.

В Україні фізичне виховання 3 найдавніших часів мало військовоприкладний характер. Система фізичної підготовки молоді була спрямована на 
використання засобів військово-фізичного виховання, народні ігри та забави, народні та бойові танці, національні види боротьби, фізичні вправи загального характеру, військові походи, полювання. Запоріжська Січ була своєрідною школою, де були створені досить ефективні спеціальні фізичні і психофізичні вправи, спрямовані на самопізнання, саморозвиток, тілесне, психофізичне вдосконалення воїнів, що приводило до загартування здоров’я, сили, спритності [4].

Сокільський рух бере свій початок з Галичини, безпосередньо зі Львова (1894-1939), він є засобом фізичного виховання всього народу і покликаний зміцнювати його силу, мужність, гартуванням тіла і волі. Окрім традиційних організацій «Сокола» i «Січі», які утворилися відповідно до історичних обставин на західноукраїнських землях (1918-1939) були створені нові товариства «Пласт», «Луч». Мета цих товариств - всебічне плекання руханки і здоров’я, відродження фізичного виховання і вдосконалення молоді. Робота у товариствах була скерована на загартування людини, зміцнення фізичного стану, це в свою чергу було активним вкладом в організацію суспільнооздоровчого життя у регіонах України [4].

В процесі розвитку людства проблема безпеки здоров“я і способу життя почала набувати соціального характеру.

Французький дослідник Мішель Міндер пропонує свою книжку «Поле педагогічної дії» - це дослідження проблем школи одночасно на соціологічному та порівняльно-педагогічному рівнях. Автор грунтовно розглядає зміст і значення цих напрямків діяльності школи, основною метою яких $є$ підготовка молоді до життя в сучасному високорозвинутому суспільстві [4].

Беручи до уваги публікації Спіріна О. [5]., Ціось Н. [6]., можемо із впевненістю зазначити, що шкільна реформа готувалась в умовах високого педагогічного піднесення. Тому в школах України кінця XIX - початку ХХ століття педагогічні колективи намагаються створити всі умови для розвитку дитячої індивідуальності. Будь-яке завдання, що ставиться перед дітьми, повинне мати в собі стимул творчості, враховуватись i розподілятись згідно 3 дитячою індивідуальністю і 3 усвідомленням проблем, які постають перед дітьми.

На думну Міхеєнко О. [3] виховання особистості - це одна 3 тих сфер діяльності школи, яка вимагає від сучасного вчителя співпраці 3 іншими соціалізуючими інституціями - громадою, церквою, правоохоронними органами, сім'єю. Отже, навчання учнівської молоді адекватному опануванню формами поведінки у різних життєвих ситуаціях, допоможе їм вести здоровий спосіб життя та швидкій адаптації до умов сьогодення.

Мета статті - обгрунтувати доцільність просвітницької діяльностті для формування здорового способу життя майбутнього покоління.

Виклад основного матеріалу. У своєму огляді ми, взяли до уваги роботи науковців пострадянського періоду при цьому стало зрозумілим, що проблема 
Журнал«Герспективитаіновації наукиљ

(Серія«Гедагогіка», Серія«Гтихологія», Серія«Медицинв»

№1(6) 2022

здорового способу життя школярів розв'язувалась за допомогою фізичного виховання. Фізичне виховання об'єднювало в собі систему заходів, які розвивали, вдосконалювали і контролювали здоровий спосіб життя дітей та підлітків. Засобами фізичного виховання необхідно вважати різноманітні фізичні вправи, рухливі ігри, гімнастика, вправи, які виконуються в різних природних умовах. Організаційними формами фізичного виховання вважаються урочні, позаурочні та позашкільні.

За останні десятиліття в галузі фізичної культури і спорту накопичено великий досвід роботи науковців, що грунтується на матеріалі широкого кола наукових досліджень в галузі використання фізичних вправ для здорового способу життя.

Вважаємо, за необхідне відзначити, що науковці розглядали потребу здорового способу життя, не тільки як педагогічну проблему, але як соціальну, намагаючись визначити місце здорового способу життя у системі освіти.

Окрім цього, дослідники виділяють сім нових гуманістичних принципів у стосунках дітей і дорослих Принцип рівності - світ дітей і дорослих вдосконалення рівних прав, їх гідності і недоліків, які доповнюють одне одного. Принцип діалогізму - цілісний діалог двох світів дитячого і дорослого. Принцип існування - світ дитинства і світ дорослих повинні підтримувати суверенітет. Принцип волі - дати дітям волю у виборі індивідуальної траєкторії. Принцип єдиного розвитку - процес розвитку світу дітей іде паралельно з розвитком світу дорослих. Принцип єдності - світ дітей i дорослих складається 3 одного світу. Принцип сприйняття - особливості людини, повинні сприйматися іншими людьми, такими якими є на справді [5].

На сьогоднішній день існує безліч оздоровчо-профілактичних програми 3 фізичної культури і спорту для різних вікових груп населення.

Так наковці пропонують навчально-профілактичні програми: Подорожня Ю., програма профілактики «Формуання в учнівської молоді навичок ведення здорового способу життя»; Воронцова Т., Оржеховська В., Пономаренко програма навчального курсу для учнівської молоді старшого підліткового та юнацького віку «Формування здорового способу життя та профілактика ВІЛіСНІДу»; також пронуються такі програми: «Національна програма патріотичного виховання наслення, формування здорового способу життя, розвитку духовності та зміцнення маральних засад суспільства; соціальна програма «Неalthy Schools: заради здорових і радісних школярів» розраховані для учнівської молоді, які можуть ефективно реалізуватися в оздороувчих центрах, освітніх закладах.

Завдання цих програми: дати учнівській молоді об’єктивну інформацію про дію куріння, алкоголю, наркотиків на здоров'я підлітків і виробити стійкий психологічний захист від патологічного зваблювання; виробити навички вирішення складних задавдань в необхідних ситуаціях; формування відповідальної внутрішньої позиції щодо свого здоров'я на основі позитивних перспективних мотивів; виробити певні навички поведінки, які посприяють 
введенню здорового способу життя.

В результаті проведеного дослідження ми, прийшли до висновку, що широко розповсюджене вживання паління та вживання алкоголю серед підлітків, в період самоствердження особистості школярів.

Науковеці вважаюит, що на формування потреби здорового способу життя підлітків безпосередньо впливають об'єктивні та суб'єктивні чинники $[2,5]$.

До об’єктивних чинників відносять: Економічне та соціальне благополуччя. Діти із соціально неблагополучних, ізольованих i незабезпечених житлом сімей, батьки яких малозабезпечені - мають більше шансів пристрастнення до негативних звичок. Суспільна невлаштованість проживання у нестандартних умовах. Часті переводи i переїзди підлітків. Доступність алкоголю, тютюну, наркотиків в сім’і, школі.

Суб’єктивні фактори: Сімейна вседозволеність. Паталогічні форми виховання. Вживання алкоголю батьками і позитивне ставлення до цього. Відсутність бажання навчатись у школі. Спілкування 3 друзями які вживають алкоголь та наркотики. Відсутність занять спортом, руховою активністю.

Проаналізувавши джерелознавчі матеріали 3 досліджуваної проблеми нами зазначено, що саме розроблені програми ведуть просвітницьку роботу в освітній та соціальній сферах. Такий підхід дозволяє авторці виділити, що саме освітні, соціальні, бізнес-структури та релігійні організації можуть допомогти в реалізації завдань профілактичних і оздоровчих програм. Надати підтримуку, керувати і координувати процес формування здорового способу життя учнівської молоді.

Вагоме значення для формування здорового способу життя української молоді має культурно-просвітницька діяльності педагогів. Позитивної оцінки заслуговує робота просвітницьких центрів: «Аналітично-інформаційний та просвітницький центр демократія XXI століття», церковних та спортивних громад, широких прошарків соціальних осередків, які мають провідний напрям і ведуть національно-культурно-просвітницьку роботу серед молоді. Розбудовуючи науковий сегмент української науки, завжди приділяв увага учнівської молоді просвітницьким завданням.

Характеризуючи здоровий спосіб життя, слід пам'ятати, що він є основою безпеки життєдіяльності людини в суспільстві. Тому функції здорового способу життя значно ширші, вони виходять за рамки чисто медичної проблеми, бо саме поняття «здоровий спосіб життя» багатогранне. Узагальнення дослідження з цієї проблеми дозволяє виділити п’ять траєкторій просвітницького руху у формуванні здорового способу життя учнівської молоді: культурно-просвітницький, фізкультурно-оздоровчий, реабілітаційнопрофілактичний, загальногігіенічний, рекреаційно-екологічний.

Теоретичними основами дослідження проблеми просвітницької діяльності в освітньо-соціальній сфері формування молодого покоління виступають соціально-історичні та психолого-педагогічні передумови формування 
Журнал«Герспективитаіновації наукиљ

(Серія«Гедагогіка», Серія«ГЕихологія», Серія«Медицина»

№1(6) 2022

здорового способу життя учнівської молоді i, як потреби збереження здоров’я та довголіття.

Розгляд соціально-історичних передумов дозволяє заакцентувати нашу увагу на тому, що в історичному аспекті проблема здоров'я і здорового способу життя набула свого значення взалежності від кліматичних, соціальних і культурно-побутових особистостей розвитку людства, зокрема постановка вченими цього питання, як важливої соціальної проблеми дозволяє простежити еволюцію іiї сутності від вчинків та думок людини, зовнішніх умов iii життя від особливостей оточуючих обставин, діяльності та індивідуальних нахилів до виховання «здорового духу в здоровому тілі»; від турботи про охорону здоров'я дітей, про гігієну і режим дня, до забезпечення здоров'я дітей і створення для них оптимальних умов навколишнього середовища, від об'єктивних потреб сучасного суспільного розвитку до комплексу оздоровчих заходів, що забезпечить гармонійний розвиток i зміцнення здоров’я, підвищить працездатність людей, продовжить їх творче довголіття.

Проаналізувавши досвід теорії та практики з питань формування потреби здорового способу життя в учнівської молоді виявили, що: проблему здоров'я і життя потрібно розглядати як найвищу людську цінність, і шукати засоби i методи їх підтримки; для наукового обгрунтування процесу флотування здорового способу життя учнівської молоді потрібно врахувати сутність, зміст шкільних, оздоровчи, профілактичних програм 3 формування здорового способу життя, виділити структурні компоненти освітніх програм 3 формування здорового способу життя учнівської молоді.

В процесі педагогічного спостереження встановлено, що лише третина школярів обізнані з правилами формування здорового способу життя, тому просвітницька діяльність вимагає системного підходу, який підвищить мотивацію молоді до ведення здорового способу життя.

Виходячи 3 теоретико-методологічних засад проблеми формування здорового способу життя, обгрунтовано програми формування та профілактики здорового способу життя, що мають на меті формувати потребу, дотримання установлених правил рухового режиму, харчування, праці та відпочинку, визначено структури які можуть сприяти формуванню у сучасної молоді ведення здорового способу життя.

Насамперед, запропоновано особисто-індивідуальний підхід до розвитку учнівської молоді, який формує самосвідомість, набуває ціннісних орієнтацій компетентності, автономності, усвідомлення ефективності просвітницької діяльності у формуванні здорового способу життя учнівської молоді. Просвітницька діяльність у формуванні здорового способу життя означає саме внутрішній розвиток, вироблення педагогічного світогляду, філософськопедагогічної концепції, установок, що формує особистісний характер, своєрідність поведінки та здатність проживати в сучасному суспільстві.

Просвітницька діяльність розглядається як складна система, яка функціонує відповідно до цілей та принципів формування здорової 
особистості. У процесі роботи поступово визначається кожний елемент системи, який водночас виконує функцію підсистеми i це спрямовує на створення структурної моделі просвітницької діяльність у формуванні здорового способу життя учнівської молоді.

Педагогічна практика свідчить, що просвітницька діяльність для здійснення своїх функцій може використовувати різні форми роботи 3 молоддю і має усі можливості вивільнити індивідуальні спроможності молоді, створити умови для позитивного свідомого вибору засад здорового способу життя.

Висновки. Здійснення контекстуально-компаративістичного аналізу педагогічних поглядів до проблеми просвітницької діяльності у формуванні здорового способу життя учнівської молоді визначено, що саме ініціатива: освітніх, соціальних, бізнес-структур, релігійних організацій мають підтримувати, керувати і координувати процес формування здорового способу життя населення України.

Залишається не вивченою, потрібно простежити, по-перше, вплив соціополітичних та культурних чинників на формування світогляду учнівської молоді щодо формування здорового способу життя; по-друге, здійснити порівняльний аналіз педагогічних поглядів інших українських освітян, а відтак аргументовано окреслити новаційність їх педагогічно-просвітницької роботи.

\section{Лimepamypa:}

1. Балушок В. Г. Етногенез українців: до історії вивчення, питання методології. Проблеми історії країн Центральної та Східної Європи. 2016. Вип. 5. С. 239255. Режим доступу: http://nbuv.gov.ua/UJRN/Pikctse_2016_5_21
2. Ireland's
National
Strategy
to Reduce
Suicide
$2015-$ 2020https://www.hse.ie/eng/services/list/4/mental-health-services/connecting-forlife/publications/connecting\%20for\%20life.pdf

3. Міхеєнко О. І. Валеологія: Основи індивідуального здоров'я людини Університетська книга. 2009. 400 с. ISBN 978-966-680-4344http://194.44.152.155/elib/local/sk779511.pdf

4. Педагогічна освіта: теорія i практика. Збірник наукових пращь Кам'янецьПодільський національний університет імені Івана Огієнка. Інститут педагогіки НАПН України [гол. ред. Лабунець В.М.]. Вип.19 (2-2015). Ч.1. Кам'янець-Подільский. 2015. 324 с.

5. Спірін О.М. Методологічні засади розвитку сучасних систем вищої освіти Вісник Житомирського державного університету імені Івана Франка. 2005. № 20. С. 104-109. http://eprints.zu.edu.ua/14369/1/\%D0\%9C\%D0\%B0\%D0\%BA\%D0\%B5\%D1\%82.\%20\%D0\%B2\%D0 \%B8\%D0\%BF\%D1\%80.pdf C. 8-10

6. Ціось Н., Становлення педагогічно-просвітницької діяльності в країні (кін. XIX - поч. XX ст.) Збірник наукових праџь Актуальні проблеми професійно-педагогічної освіти та стратегії розвитку. За заг. ред. О.А. Дубасенюк, Л.В. Калініної, O.C. Антонової. Житомир. Вид-во ЖДУ. 2006. C. 8-10 http://eprints.zu.edu.ua/ 14369/1/\%D0\%9C\%D0\%B0\%D0\%BA\%D0\%B5\%D1\%82.\%20\%D0\%B2\%D0\%B8\%D0\%BF\% D1\%80.pdf C. 8-10 


\section{References:}

1. Balushok, V. G. (2016). Etnogenez ukraïnciv: do istoriï vivchennja, pitannja metodologiï [Ethnogenesis of Ukrainians: to the history of study, questions of methodology]. Problemi istoriï kraïn Central'noï ta Shidnoï Cvropi-Problems of the history of Central and Eastern Europe, 5, 239-255 [in Ukrainian].

2. Ireland's National Strategy to Reduce Suicide 2015-2020 [Ireland's National Strategy to Reduce Suicide 2015-2020]. www.hse.ie Retrived from https://www.hse.ie/eng/services/list/4/ mentalhealth-services/connecting-for-life/publications/connecting\%20for\%20life.pdf [in Ukrainian].

3. Miheenko, O. I. (2009). Valeologija: Osnovi individual'nogo zdorov'ja ljudini [Valeology: Fundamentals of individual human health]. Universitets'ka kniga [in Ukrainian].

4. Pedagogichna osvita: teorija i praktika. Zbirnik naukovih prac' Kam'janec'-Podil's'kij nacional'nij universitet imeni Ivana Ogienka. Institut pedagogiki NAPN Ukraïni [Pedagogical education: theory and practice. Collection of scientific works Kamyanets-Podilsky National University named after Ivan Ogienko. Institute of Pedagogy of the National Academy of Pedagogical Sciences of Ukraine], 19 (2-2015) [in Ukrainian].

5. Spirin, O.M. (2005). Metodologichni zasadi rozvitku suchasnih sistem vishhoï osviti [Methodological bases of development of modern systems of higher education]. Visnik Zhitomirs'kogo derzhavnogo universitetu imeni Ivana Franka - Bulletin of Zhytomyr State University named after Ivan Franko, 20, -109 [in Ukrainian].

6. Cios', N. (2006). Stanovlennja pedagogichno-prosvitnic'koï dijal'nosti v kraïni (kin. HIH - poch. HH st.) [Formation of pedagogical and educational activities in the country (late XIX - early XX centuries.)]. Zbirnik naukovih prac' Aktual'ni problemi profesijnopedagogichnoï osviti ta strategï rozvitku - Collection of scientific papers Current issues of vocational education and development strategies, 8-10 [in Ukrainian]. 